\title{
Agronomic aspects of soybean plants subjected to deficit irrigation
}

\author{
Antônia C. Nunes ${ }^{1}$, Francisco M. L. Bezerra², Roberta A. e Silva ${ }^{3}$, \\ José L. C. da Silva Júnior ${ }^{4}$, Flávia B. Gonçalves ${ }^{4}$ Geovana A. Santos ${ }^{4}$ \\ ${ }^{1}$ Fundação Universidade Federal do Tocantins/Campus de Palmas. Palmas, TO. E-mail: clemildanunes@yahoo.com.br (Corresponding author) \\ ${ }^{2}$ Universidade Federal do Ceará/Centro de Ciências Agrárias/Departamento de Engenharia Agrícola. Fortaleza, CE. E-mail: mbezerra@ufc.br \\ ${ }^{3}$ Universidade Federal de Campina Grande/Centro de Tecnologia e Recursos Naturais/Unidade Acadêmica de Ciências Atmosféricas. Campina \\ Grande, PB. E-mail: beta_araj@yahoo.com.br \\ ${ }^{4}$ Fundação Universidade do Tocantins/Centro de Ciências Agrárias/Curso de Engenharia Agronômica. Palmas, TO. E-mail: jose.lc@unitins.br; \\ flaviabarreira@hotmail.com; geovanalsan1@gmail.com
}

Key words:

irrigation management yield

Glycine max (L.) Merril

\begin{abstract}
A B S T R A C T
This study aimed to evaluate the behavior of soybean plants subjected to irrigation management with controlled water deficits in different phenological stages. The research was conducted in an experimental area of the Federal University of Tocantins (UFT), in Palmas-TO, Brazil. The experimental design was randomized blocks with four replicates, and treatments arranged in a split-plot scheme. The plots consisted of irrigation levels that induced plants to water deficit in the vegetative stage, reproductive stage and throughout the entire cycle, based on potential crop evapotranspiration (ETpc). The subplots corresponded to two soybean cultivars (M9144RR and TMG1288RR). The following agronomic variables were evaluated: days until flowering, days until maturation, plant height, first pod height, number of pods per plant, stem diameter, leaf area and yield. Irrigation management with moderate water deficit, $50 \%$ of ETpc, in the vegetative stage, promoted the best agronomic characteristics and contributed to increase the yield of the evaluated soybean cultivars, especially M9144RR.
\end{abstract}

\section{Palavras-chave:}

manejo de irrigação

produtividade

Glycine max (L.) Merril

\section{Aspectos agronômicos de plantas de soja submetidas a déficit hídrico}

\begin{abstract}
R E S U M O
No presente trabalho objetivou-se avaliar o comportamento da soja submetida a manejos de irrigação com déficit hídrico controlado em diferentes fases fenológicas, na cultura da soja. A pesquisa foi conduzida no período de junho a outubro de $2014 \mathrm{em}$ uma área experimental da UFT em Palmas, TO. O delineamento experimental foi em blocos ao acaso em esquema de parcelas subdivididas. As parcelas foram constituídas por lâminas de irrigação que induziram as plantas a déficit hídrico no período vegetativo, reprodutivo e durante todo o ciclo tendo, como referência evapotranspiração potencial da cultura (ETpc) com quatro repetições. As subparcelas corresponderam a duas cultivares de soja: M9144RR e TMG1288RR. As variáveis avaliadas foram: dias para florescimento, dias para maturação, altura da planta, altura da primeira vagem, número de vagens por planta, diâmetro do caule, área foliar e produtividade. O manejo da irrigação com déficit hídrico moderado, $50 \%$ da ETpc, no período vegetativo promoveu as melhores características agronômicas além de contribuir para o aumento da produtividade das cultivares de soja avaliadas com destaque para a cultivar M9144RR.
\end{abstract}




\section{INTRODUCTION}

Originated in Eastern Asia (Lee et al., 2011), soybean (Glycine max (L.) Merrill) is an annual herbaceous leguminous plant and the high contents of oil and protein in its grains place it among the main sources of vegetal oil and protein for human and animal consumption in the world, besides being currently one of the products with highest importance in the Brazilian economy (Barbosa et al., 2013).

The success of all this complex, however, is highly dependent on climatic conditions (Morando et al., 2014), especially with respect to the irregular distribution of rains, since water is considered as one of the most required resources.

The soybean crop needs, on average, 550 to $800 \mathrm{~mm}$ of water during the entire cycle, which varies depending on the area, sowing period, type of soil and cultivar sown (Farias et al., 2001). However, growing annual vegetables show different phenological stages along their cycles, each one with a different water demand (Grieu et al., 2008).

Fereres \& Soriano (2007) proposed the concept of deficit irrigation, which is the application of water depths lower than those estimated by the traditional methodologies, in the different phenological stages.

In this context, considering the relevance of the subject and the national importance of the soybean crop, this study aimed to evaluate the agronomic performance and yield of soybean subjected to irrigation managements with controlled water deficit in different phenological stages.

\section{Material and Methods}

The experiment was carried out at the field from June to October, in the 2014 off season, at the experimental station of the Federal University of Tocantins, in Palmas, TO, Brazil (10 ${ }^{\circ}$ $12^{\prime} 46^{\prime \prime} \mathrm{S} ; 48^{\circ} 21^{\prime} 37^{\prime \prime} \mathrm{W} ; 260 \mathrm{~m}$ ). The climate of the region is Aw, tropical savanna, according to Köppen's climate classification, characterized by having reasonable homogeneity, with two well-defined seasons, humid summer and dry winter, rainfall of $1300 \mathrm{~mm}$, relative air humidity of $70 \%$ and temperature of $26^{\circ} \mathrm{C}$ (annual means). The soil was classified as dystrophic Red Yellow Latosol (EMBRAPA, 2006), with sandy loam texture, and its chemical and physical characteristics are shown in Table 1.

At sowing, basal fertilization was performed in all plots and corresponded to 100 and $50 \mathrm{~kg} \mathrm{ha}^{-1}$ of $\mathrm{P}_{2} \mathrm{O}_{5}$ and $\mathrm{K}_{2} \mathrm{O}$, respectively, according to the recommendation for soybean fertilization in Cerrado soils (EMBRAPA, 2008) and based on soil fertility analysis. The fertilizers used were single superphosphate and potassium chloride, besides a commercial formulation of micronutrients, containing: $\mathrm{Fe}-\mathrm{Cu}-\mathrm{Zn}-\mathrm{Mn}-\mathrm{B}-$ $\mathrm{Mo}-\mathrm{Ni}$ at the proportions of 4.4-1.1-0.44-1.1-1.1-0.22-0.2\%, respectively. 30 days after sowing (DAS) more $50 \mathrm{~kg} \mathrm{ha}^{-1}$ of $\mathrm{K}_{2} \mathrm{O}$ were applied as top-dressing, as potassium chloride. The seeds were treated with the fungicide Captan using $120 \mathrm{~g}$ of the commercial product for $100 \mathrm{~kg}$ of seeds, followed by inoculation with Bradyrhizobium japonicum strains.

A drip irrigation system was used and the irrigation depth that served as a reference for the treatments corresponded to the potential crop evapotranspiration (ETpc), obtained through Eq. 1.

$$
\mathrm{ETpc}=\mathrm{Kc} \times \mathrm{ETo}
$$

where:

ETpc - potential crop evapotranspiration, $\mathrm{mm} \mathrm{d}^{-1}$;

ETo - reference evapotranspiration, $\mathrm{mm} \mathrm{dia}^{-1}$; and,

Kc - crop coefficient for each crop development stage, dimensionless.

Reference evapotranspiration (ETo) was calculated through the Penman-Monteith method (Allen et al., 2006). The climatic data were obtained from an automatic weather station installed in the experimental area.

The time of irrigation was quantified according to Eq. 2.

$$
\mathrm{Ti}=\frac{\mathrm{ETpc} \cdot \mathrm{E}_{\mathrm{L}} \cdot \mathrm{E}_{\mathrm{e}} \cdot \mathrm{Fc}}{\mathrm{E}_{\mathrm{i}} \cdot \mathrm{q}_{\mathrm{e}}}
$$

where:

$\mathrm{Ti}$ - time of irrigation, h;

ETpc - potential crop evapotranspiration, $\mathrm{mm} \mathrm{d}^{-1}$;

$\mathrm{E}_{\mathrm{L}}$ - spacing between irrigation lines, $\mathrm{m}$;

$\mathrm{E}_{\mathrm{e}} \quad$ - spacing between emitters, $\mathrm{m}$;

Fc - soil cover factor, dimensionless;

$\mathrm{E}_{\mathrm{i}} \quad$ - irrigation efficiency, dimensionless; and,

$\mathrm{q}_{\mathrm{e}} \quad$ - emitter flow rate, $\mathrm{L} \mathrm{h}^{-1}$.

The experimental design was in randomized blocks with four replicates and the treatments were arranged in a split-plot scheme, with 7 plots and 2 subplots. The treatments, defined as a function of water deficits in different crop stages (Table 2), were evaluated in the plots $\left(70 \mathrm{~m}^{2}, 3.5 \times 20 \mathrm{~m}\right)$ and the cultivars M9144RR and TMG1288RR were evaluated in the subplots. The total area occupied by the experiment was equal to $610 \mathrm{~m}^{2}(30.5 \mathrm{x} 20 \mathrm{~m})$, composed of 56 planting rows with 14 plants $\mathrm{m}^{-1}$. A spacing of 1 $\mathrm{m}$ was used between plots to guarantee no interference between treatments. The experimental plot consisted of four 5-m-long rows, spaced by $0.5 \mathrm{~m}$. For harvest, two lateral rows and $0.5 \mathrm{~m}$ of each end of the central rows were disregarded, which resulted in an evaluation area of $3.6 \mathrm{~m}^{2}$ per experimental plot, with 112 plants.

Table 1. Chemical and physical characteristics of a dystrophic Red Yellow Latosol in the layer of 0-0.20 $\mathrm{m}$ in the

\begin{tabular}{|c|c|c|c|c|c|c|c|c|c|c|c|}
\hline \multicolumn{8}{|c|}{ Chemical } & \multicolumn{4}{|c|}{ Physical } \\
\hline $\mathbf{P}$ & $\mathrm{K}$ & $\mathrm{Ca}$ & $\mathrm{Mg}$ & $\overline{A l}$ & \multirow{2}{*}{$\underset{\left(g_{d m^{-3}}\right)}{O M}$} & \multirow{2}{*}{$\underset{\substack{\mathrm{pH} \\
\left(\mathrm{H}_{2} \mathrm{O}\right)}}{ }$} & \multirow{2}{*}{$\begin{array}{c}\text { pH } \\
\left(\mathrm{CaCl}_{2}\right)\end{array}$} & \multicolumn{4}{|c|}{ Granulometry } \\
\hline \multicolumn{2}{|c|}{$\left(\mathrm{mg} \mathrm{dm} \mathrm{dm}^{-3}\right)$} & \multicolumn{3}{|c|}{$\left(\mathrm{cmol}_{\mathrm{c}} \mathrm{dm}^{-3}\right)$} & & & & $\left(\mathrm{kg} \mathrm{dm}^{-3}\right)$ & Clay & $\frac{\text { Silt }}{\mathrm{g} \mathrm{kq}^{-1}}$ & Sand \\
\hline 1.72 & 5.23 & 1.48 & 0.44 & 0.07 & 24.88 & 5.68 & 4.90 & 1.36 & 164.4 & 38.3 & 797.3 \\
\hline
\end{tabular}
experimental area before installation of experiment 
Table 2. Description of the treatments in the plots

\begin{tabular}{cl}
\hline Treatment & Description \\
T1 & Crop under water deficit along the entire cycle, irrigated with $25 \%$ ETpc \\
T2 & Crop under water deficit along the entire cycle, irrigated with $50 \%$ ETpc \\
T3 & Crop under no water deficit, irrigated with $100 \%$ ETpc \\
T4 & Crop under water deficit of $25 \%$ ETpc during the vegetative stage, beginning the differentiation in V1 \\
T5 & Crop under water deficit of $25 \%$ ETpc during the vegetative stage, beginning the differentiation in V1 \\
T6 & Crop under water deficit of $50 \%$ ETpc during the reproductive stage, beginning the differentiation in R1 \\
T7 &
\end{tabular}

Irrigation was daily performed early in the morning and, when there was rainfall, the value was subtracted from the applied water depth. Plants received total water depths according to Table 3.

During the experimental period, cultural and phytosanitary control were performed always when necessary.

The following characteristics were evaluated: days until flowering (DFl), defined as the number of days from sowing until the observation of one open flower on the main stem in $50 \%$ of the plants; days until maturation (DM), as the number of days from sowing until the day on which plants showed $95 \%$ of mature pods; plant height $(\mathrm{PH})$, as the distance between soil surface and the apex of the main stem; first pod height (FPH), as the distance between soil surface and the first pod, both variables measured in centimeter using a measuring tape; number of pods per plant (NPP), through the direct count of the pods; and stem diameter (SD), measured at a height of approximately $5 \mathrm{~cm}$ from soil surface, using a digital caliper, in millimeters.

Leaf area was also analyzed using an optical electronic planimeter (LI -COR - LI 3100), by randomly collecting four plants in each treatment. This analysis was performed from August 24 to 30, 2014, as plants reached the R5.1 stage (Fehr et al., 1971), which is the stage in which the plant reaches its maximum leaf area, rapidly decreasing subsequently.

Harvest was performed 95 and 120 DAS always when plants reached physiological maturation and grain yield $(\mathrm{Y})$ was expressed in grams per plot. The values were later transformed into $\mathrm{kg} \mathrm{ha}^{-1}$, while grain moisture was corrected to $13 \%$.

The significance of the treatments was evaluated using analysis of variance by $\mathrm{F}$ test at 0.01 probability level and, when significant effect was observed, means were compared by the Scott-Knott test at 0.05 probability level. The analyses were performed using the statistical program Assistat, beta version 7.7 .

\section{Results AND Discussion}

The summary of the analysis of variance for the parameters related to soybean agronomic characteristics and yield is shown in Table 4.

The treatments influenced, at 0.01 probability level by $\mathrm{F}$ test, all evaluated characteristics, as well as the interaction between treatments and cultivars. Regarding the cultivars, there was also significant difference by $\mathrm{F}$ test $(\mathrm{p} \leq 0.01)$, except for leaf area, which differed at 0.05 probability level, and the variables plant height (PH) and number of pods per plant (NPP) did not show significant difference.

In the follow-up analysis of the interaction of some of the agronomic characteristics, there was difference between the cultivars M9144RR and TMG1288RR for days until flowering, days until maturation and first pod height; however, there was no difference with respect to plant height (Table 5). For the water deficit, M9144RR plants under water deficit conditions

Table 3. Irrigation depths, in millimeters, applied in the soybean crop

\begin{tabular}{|c|c|c|c|c|c|c|c|}
\hline \multirow[b]{2}{*}{ Treatment } & \multirow{2}{*}{$\begin{array}{c}\text { Initial } \\
\text { M9144RR and TMG1288RR }\end{array}$} & \multicolumn{2}{|c|}{ VS } & \multicolumn{2}{|c|}{ RS } & \multicolumn{2}{|c|}{ Total } \\
\hline & & M9144 RR & TMG1288RR & M9144RR & TMG1288 RR & M9144RR & TMG1288RR \\
\hline $\mathrm{T} 1$ & 18.9 & 33.6 & 40.2 & 95.9 & 86.3 & 148.4 & 145.4 \\
\hline T2 & 18.9 & 71.2 & 80.5 & 185.9 & 194.0 & 276.0 & 293.3 \\
\hline T3 & 18.9 & 142.4 & 160.9 & 414.5 & 387.9 & 575.9 & 567.7 \\
\hline T4 & 18.9 & 33.6 & 40.2 & 426.3 & 387.9 & 478.8 & 447.0 \\
\hline T5 & 18.9 & 71.2 & 80.5 & 414.5 & 387.9 & 504.6 & 487.3 \\
\hline T6 & 18.9 & 142.4 & 160.9 & 93.0 & 86.3 & 254.3 & 266.1 \\
\hline $\mathrm{T} 7$ & 18.9 & 142.4 & 160.9 & 207.3 & 194.0 & 368.6 & 373.8 \\
\hline
\end{tabular}

VS - Vegetative stage; RS - Reproductive stage

Table 4. Summary of analysis of variance for agronomic characteristics and yield of soybean subjected to water deficit

\begin{tabular}{|c|c|c|c|c|c|c|c|c|c|}
\hline \multirow{2}{*}{ SV } & \multirow{2}{*}{ DF } & \multicolumn{8}{|c|}{$F$ test } \\
\hline & & DFI & $\overline{D M}$ & $\mathrm{PH}$ & $\overline{F P H}$ & $\overline{N P P}$ & SD & $\mathrm{PH}$ & $\bar{Y}$ \\
\hline Blocks & 3 & $4.52^{\star}$ & $2.12^{\mathrm{ns}}$ & $7.97^{\star \star}$ & $3.16^{\star}$ & $0.91^{\mathrm{ns}}$ & $4.06^{\star}$ & - & $0.13^{\mathrm{ns}}$ \\
\hline Treatment ( $\mathrm{T})$ & 6 & 20.41 ** & 44.68 ** & $33.81 * *$ & $66.51^{* *}$ & $191.7^{* *}$ & $64.41^{* *}$ & $23.49 * *$ & $124.28 * *$ \\
\hline Residual (T) & 18 & - & - & - & - & - & - & - & - \\
\hline Cultivar (C) & 1 & $1564.97^{\star *}$ & $46.17^{\star \star}$ & $3.81^{\mathrm{ns}}$ & $10.51^{\star \star}$ & $2.03^{\mathrm{ns}}$ & $74.69^{*}$ & $5.05^{*}$ & $19.61^{\star \star}$ \\
\hline Interaction T x C & 6 & $17.24^{\star \star}$ & $45.22^{\star \star}$ & $4.41 * \star$ & $23.78^{\star \star}$ & $16.77^{\star \star}$ & $26.84^{\star *}$ & $9.66^{\star \star}$ & $26.81^{\star \star}$ \\
\hline Residual & 21 & - & - & - & - & - & - & - & - \\
\hline CV - T (\%) & - & 0.37 & 2.46 & 7.39 & 4.48 & 5.10 & 4.39 & 11.24 & 14.2 \\
\hline CV - C (\%) & - & 0.45 & 0.92 & 6.21 & 3.54 & 7.99 & 4.17 & 10.00 & 8.73 \\
\hline
\end{tabular}

SV - Source of variation; DF - Degrees of freedom; CV - Coefficient of variation; ${ }^{n}$ Not significant; **Significant at 0.01 probability level by F test; * significant at 0.05 probability level by $F$ test; days until flowering (DFI); days until maturation (DM); plant height (PH); first pod height (FPH); number of pods per plant (NPP); stem diameter (SD); leaf area (LA) and yield (Y) 
Table 5. Means of the interaction between treatments and cultivars for the variables: days until flowering (DFI), days until maturation (DM), plant height $(\mathrm{PH})$ and first pod height (FPH) of soybean plants subjected to water deficit

\begin{tabular}{|c|c|c|c|c|c|c|c|c|}
\hline \multirow{3}{*}{ Treatment ${ }^{*}$} & \multicolumn{8}{|c|}{ Variable } \\
\hline & \multicolumn{2}{|c|}{ DFI } & \multicolumn{2}{|c|}{ DM } & \multicolumn{2}{|c|}{$\mathrm{PH}(\mathrm{cm})$} & \multicolumn{2}{|c|}{ FPH (cm) } \\
\hline & M9144RR & TMG1288RR & M9144RR & TMG1288RR & M9144RR & TMG1288RR & M9144RR & TMG1288RR \\
\hline T1 & 41.0bB & $47.0 \mathrm{aA}$ & $98.7 \mathrm{~dB}$ & $101.5 \mathrm{dA}$ & $48.7 \mathrm{dA}$ & $47.7 \mathrm{dA}$ & $17.7 \mathrm{bA}$ & $14.2 \mathrm{~dB}$ \\
\hline T2 & $43.0 \mathrm{aB}$ & $47.0 \mathrm{aA}$ & $99.5 \mathrm{~dB}$ & $111.2 \mathrm{cA}$ & $56.9 \mathrm{cA}$ & $52.7 \mathrm{dA}$ & $16.4 \mathrm{bA}$ & $13.4 \mathrm{~dB}$ \\
\hline T3 & $43.0 \mathrm{aB}$ & $46.0 \mathrm{bA}$ & $116.0 \mathrm{aA}$ & $114.2 \mathrm{bB}$ & $65.2 \mathrm{bB}$ & $78.9 \mathrm{aA}$ & $14.1 \mathrm{cB}$ & $21.5 \mathrm{cA}$ \\
\hline T4 & $41.0 \mathrm{bB}$ & $46.0 \mathrm{bA}$ & 113.0bA & $111.5 \mathrm{cB}$ & $57.1 \mathrm{cA}$ & $60.5 \mathrm{cA}$ & $17.8 \mathrm{bA}$ & $15.3 \mathrm{~dB}$ \\
\hline T5 & $43.0 \mathrm{aB}$ & $47.0 \mathrm{aA}$ & $114.2 \mathrm{bB}$ & 116.7aA & $59.6 \mathrm{cA}$ & $62.5 \mathrm{cA}$ & $14.5 \mathrm{cA}$ & $14.9 \mathrm{dA}$ \\
\hline T6 & $43.0 \mathrm{aB}$ & $46.0 \mathrm{bA}$ & $101.7 \mathrm{cA}$ & $102.2 \mathrm{dA}$ & $69.2 \mathrm{bA}$ & $68.2 \mathrm{bA}$ & $23.0 \mathrm{aB}$ & $27.8 \mathrm{bA}$ \\
\hline T7 & $43.0 \mathrm{aB}$ & 47.0aA & $112.7 \mathrm{bA}$ & $111.2 c B$ & 73.8aA & 74.1aA & $23.6 \mathrm{aB}$ & $29.9 \mathrm{aA}$ \\
\hline
\end{tabular}

* For details of treatment see Table 2; Means followed by the same letter (lowercase in columms and uppercase in rows) do not differ statistically by the Scott-Knott test at 0.05 probability level

during the vegetative stage (T1 and T4) anticipated its flowering in two days, in comparison to the other treatments, while for the cultivar TMG1288RR there was an anticipation of only one day in the treatments T3, T4 and T6. However, considering that there are treatments with and without water deficit in both groups, it is possible to infer that this difference is not related to water deficit effects, but to the non-uniformity in the flowering process, which is common in some soybean cultivars.

As to physiological maturation, the severe water deficit during the entire cycle and in the reproductive stage (T1 and T6) influenced both cultivars, causing anticipation of maturation. This response was also observed in the cultivar M9144RR for a 50\% water deficit during its entire cycle (T2), possibly because this cultivar has greater sensitivity with respect to this characteristic. These results agree with those of Cruz et al. (2010), who also observed that soybean cultivars shortened their cycles by up to 11 days when sown in periods that promoted unfavorable climatic conditions to the plants, a fact that is mainly attributed to the low rainfall indices.

For plant height $(\mathrm{PH})$, plants subjected to water stress along the entire cycle (T1 and T2) and in the vegetative stage (T4 and T5) showed the greatest values. In addition, this variable was sensitive only to water stress, with no variation between cultivars. These results can be explained considering that, under water deficit, the first alteration that occurs in the plants is turgor reduction, thus causing decrease in growth (Ferrari et al., 2015).

For the variable first pod height (FPH), the cultivar M9144RR showed the lowest values in the treatments without water deficit and with moderate water deficit only in the vegetative stage, T3 and T5, respectively (Table 5). Probably, for plants suffering water stress in the reproductive stage, the abortion of pods occurs at lower positions and, consequently, the pods concentrate at higher positions, causing greater values of this variable. In TMG1288RR plants, FPH means followed the same trend observed for $\mathrm{PH}$, with the lowest values corresponding to the treatments with water deficit in the vegetative stage and in the entire cycle.

Plants of the cultivar M9144RR showed the highest number of pods per plant (NPP), stem diameter (SD) and leaf area (LA) when subjected to the treatments without water deficit (T3) and with $50 \%$ water deficit in the vegetative stage (T5), and there was no statistical difference between them. Hence, it can be inferred that, for this cultivar, even if there is a moderate water deficit in the vegetative stage, there is no damage to these characteristics. The other treatments (T1, T2, T4, T6 and T7), however, were statistically inferior, which demonstrates the need for a thorough investigation on the water deficit level to be imposed on the crop, in order not to cause damage on agronomic characteristics that are important for a good development of the plant.

The reduction in the number of pods plant ${ }^{-1}$ for the cultivar M9144RR in the treatments with severe and moderate water deficit along the entire cycle and in the reproductive stage, $\mathrm{T} 1$, T2, T6 and T7, respectively, may be related to the abortion of flowers, because, according to Nelson et al. (2004), the highest water demand by soybean occurs during the period of flowering/grain filling. Therefore, the occurrence of water deficit in this period cause physiological alteration in the plants and lead to a premature fall of leaves, flowers and abortion of pods, while in T4, even with full irrigation in the remaining stages, it was not sufficient to recover the effects of the water deficit imposed on plants during the vegetative stage for this variable.

Under the water deficit conditions imposed by the treatments T1, T2, T4, T6 and T7 (Table 6), the decrease in SD values for the cultivar M9144RR may be due to a reduction in stem biomass production, because, according to Shao et

Table 6. Means of the interaction between treatments and cultivars for the variables: first pod height (FPH), number of pods plant ${ }^{-1}$ (NPP), stem diameter (SD), leaf area (LA) and yield (Y) of soybean plants subjected to water deficit

\begin{tabular}{|c|c|c|c|c|c|c|c|c|}
\hline \multirow{3}{*}{ Treatment ${ }^{*}$} & \multicolumn{8}{|c|}{ Variable } \\
\hline & \multicolumn{2}{|c|}{ NPP } & \multicolumn{2}{|c|}{ SD (mm) } & \multicolumn{2}{|c|}{$\mathrm{LA}\left(\mathrm{cm}^{2}\right)$} & \multicolumn{2}{|c|}{$\mathrm{Y}\left(\mathrm{kg} \mathrm{ha}^{-1}\right)$} \\
\hline & M9144RR & TMG1288RR & M9144RR & TMG1288RR & M9144RR & TMG1288RR & M9144RR & TMG1288RR \\
\hline T1 & $12.1 \mathrm{cB}$ & $28.4 \mathrm{bA}$ & $4.19 \mathrm{cB}$ & $5.09 \mathrm{cA}$ & $496.50 \mathrm{cA}$ & $631.05 \mathrm{cA}$ & $706.15 \mathrm{fA}$ & $918.65 \mathrm{fA}$ \\
\hline T2 & 24.1 bB & $37.8 \mathrm{bA}$ & $5.71 \mathrm{bA}$ & $5.48 \mathrm{bA}$ & $645.90 \mathrm{~dB}$ & $1302.39 \mathrm{aA}$ & $1,342.62 \mathrm{eB}$ & $2,326.05 \mathrm{dA}$ \\
\hline T3 & $56.7 \mathrm{aA}$ & $36.5 \mathrm{bB}$ & $6.70 \mathrm{aA}$ & $5.42 \mathrm{bB}$ & 2399.49 aA & $1309.03 \mathrm{aB}$ & $4,781.99 \mathrm{bA}$ & $3,643.14 \mathrm{bB}$ \\
\hline T4 & 26.7 bA & $24.4 \mathrm{cA}$ & $4.49 \mathrm{cA}$ & $4.43 \mathrm{dA}$ & $1276.58 \mathrm{bA}$ & $1065.83 \mathrm{bA}$ & $3,375.35 \mathrm{cA}$ & $2,672.80 \mathrm{cB}$ \\
\hline T5 & 53.8 aB & $74.5 \mathrm{aA}$ & $6.56 \mathrm{aA}$ & $5.93 \mathrm{aB}$ & $2188.74 \mathrm{aA}$ & $1506.27 \mathrm{aB}$ & $5,271.26 \mathrm{aA}$ & $3,994.66 \mathrm{aB}$ \\
\hline T6 & $22.1 \mathrm{bA}$ & $14.7 \mathrm{cA}$ & $5.99 \mathrm{bA}$ & $4.46 \mathrm{~dB}$ & $1431.45 \mathrm{bA}$ & $1024.69 \mathrm{bB}$ & $1,395.13 \mathrm{eA}$ & $1,636.30 \mathrm{eA}$ \\
\hline $\mathrm{T} 7$ & $24.7 \mathrm{bA}$ & $19.1 \mathrm{cA}$ & $5.68 \mathrm{bA}$ & $4.87 \mathrm{cB}$ & $1446.46 \mathrm{bA}$ & $1561.10 \mathrm{aA}$ & $1,994.51 \mathrm{dA}$ & $1,820.93 \mathrm{eA}$ \\
\hline
\end{tabular}

* For details of treatment see Table 2; Means followed by the same letter (lowercase in columms and uppercase in rows) do not differ statistically by the Scott-Knott test at 0.05 probability level 
al. (2008), water deficit, besides decreasing the absorption of nutrients, reduces the photosynthetic rate due to the reduction in internal $\mathrm{CO}_{2}$ concentration caused by stomatal closure, which may consequently damage the formation of plant tissues.

Following the same trend, the lowest values of LA for the cultivar M9144RR in the treatments T1, T2, T4, T6 and T7 are consistent with those reported by Taiz \& Zeiger (2009), who claim that leaf area reduction is one of the first reactions of the plant in response to water deficit and is a morphophysiological mechanism to equilibrate water conservation by plants and $\mathrm{CO}_{2}$ assimilation rate for the production of carbohydrates. On the other hand, the cultivar TMG1288RR showed reduction in LA values only in the treatments of severe water deficit, imposed on plants during the entire cycle (T1), in the vegetative stage (T4) or in the reproductive stage (T6).

The cultivar TMG1288RR showed the highest number of pods in the treatment T5, which suggests that, for this cultivar, a moderate water deficit (50\%) only in the vegetative stage may act as a stimulus to a larger production of pods. On the other hand, the treatments with severe and moderate water deficit along the entire cycle (T1 and T2) did not differ statistically from T3 (without deficit) for the variable NPP. Hence, it is assumed that plants that had been under stress since the beginning of the cycle made an adjustment in their morphology, reducing height and increasing the number of pods (Table 6). However, the pods contained, in their majority, one or two seeds and some were shriveled, a behavior similar to that reported by Maehler et al. (2003), who observed increase in the number of empty pods and pods with one grain, in relation to pods containing three grains, due to the lower supply of water and assimilates.

As to the variable SD, the cultivar TMG1288RR showed the highest value $(5.93 \mathrm{~mm})$ when subjected to the treatment that promoted moderate water deficit only in the vegetative (T5), which was even statistically superior to the treatment in which plants did not suffer water deficit. This once more indicates that irrigation management with moderate water deficit only in the vegetative stage may be beneficial to plants of this cultivar.

With respect to yield, both cultivars expressed their genetic potentials more satisfactorily when subjected to the treatment T5. It appears that a water restriction of 50\% ETpc in the vegetative stage does not harm yield and may even be considered as a stimulus, because this treatment was statistically superior to that without water deficit (T3), promoting increments of 10.23 and $9.65 \%$ in the cultivars M9144RR and TMG1288RR, respectively. Comparing these values with the yield estimate for the state of Tocantins, which was $2809 \mathrm{~kg} \mathrm{ha}^{-1}$ (CONAB, 2015), the cultivars M9144RR and TMG1288RR showed increments of 87.65 and $42.21 \%$, respectively, under the conditions of the treatment T5. Based on the estimated yield in Brazil, 2,967.00 kg ha-1 (CONAB, 2015), the cultivars M9144RR and TMG1288RR showed increments of 77.7 and $34.6 \%$, respectively.

These results also suggest that there might have occurred an increase in water use efficiency by the plants, because, under moderate deficiency, soybean plants tend to show only partial reduction in stomatal opening and it limits transpiration more strongly than the entry of $\mathrm{CO}_{2}$ (Kron et al., 2008). Additionally, plants reduced their growth due to the water deficit (Table 5); according to Kron et al. (2008), it is a mechanism of tolerance to the lack of water and may be considered as a strategy of energy conservation, which probably contributed to make plants more efficient in the production stage, when water conditions were more favorable.

On the other hand, the occurrence of severe deficit during the entire cycle and in the reproductive stage resulted in the highest yield reduction. These results are consistent, because Costa et al. (2008), working with other leguminous plant (cowpea), observed that under these conditions, transpiration exceeds water absorption and acts directly in plant water relationships, leading to low yields.

\section{Conclusions}

Irrigation management with moderate water deficit, 50\% ETpc, in the vegetative stage, promoted the best agronomic characteristics and contributed to increase the yield of the evaluated soybean cultivars, especially M9144RR.

\section{Literature Cited}

Allen, R. G.; Pereira, L. S.; Raes, D.; Smith, M. Evapotranspiración del cultivo. Roma: FAO 56, 2006. 300p.

Barbosa, M. C.; Braccini, A. de L. E; Scapim, C. A.; Albrecht, L. P.; Piccinin, G. G.; Zucareli, C. Desempenho agronômico e componentes da produção de cultivares de soja em duas épocas de semeadura no arenito caiuá. Semina: Ciências Agrárias, v.34, p.945960, 2013. http://dx.doi.org/10.5433/1679-0359.2013v34n3p945

CONAB - Companhia Nacional de Abastecimento. Acompanhamento de safra brasileira: Grãos, v.2 - Safra 2014/15, n. 6, Brasília: CONAB, março, 2015.

Costa, R. C. L.; Lobato, A. K. S.; Oliveira Neto, C. S.; Maia, P. S. P.; Alves, G. A. R.; Laughinghouse, H. D. Biochemical and physiological responses in two Vigna unguiculata (L.) Walp. cultivars under water stress. Journal of Agronomy, v.7, p.98-101, 2008. http://dx.doi.org/10.3923/ja.2008.98.101

Cruz, T. V. da; Peixoto, C. P.; Martins, M. C. Crescimento e produtividade de soja em diferentes épocas de semeadura no oeste da Bahia. Scientia Agraria, v.11, p.33-42, 2010. http://dx.doi. org/10.5380/rsa.v11i1.15941

EMBRAPA - Centro Nacional de Pesquisa de Solos. Sistema brasileiro de classificação de solos. 2. ed. Brasília: EMBRAPA-SPI, 2006. 306p.

EMBRAPA - Empresa Brasileira de 'Pesquisa Agropecuária. Calagem e adubação da soja. Londrina: Embrapa CNPSo, 2008. 12p. Circular Técnica, 61

Farias, J. R. B.; Assad, E. D.; Almeida, I. R. de; Evangelista, B. A.; Lazzarotto, C.; Neumaier, N. Nepomuceno, A. L. Caracterização de risco de déficit hídrico nas regiões produtoras de soja no Brasil. Revista Brasileira de Agrometeorologia, v.9, p.415-421, 2001.

Fehr, W. R.; Caviness, R. E.; Burmood, D. T.; Pennineton, J. S. Stage of development descriptions for soybeans, Glycine max L. Merrill. Crop Science, v.11, p.929-931, 1971. http://dx.doi.org/10.2135/ cropsci1971.0011183X001100060051x 
Fereres, E.; Soriano, M. A. Deficit irrigation for reducing agricultural water use. Journal Experimental Botany, v.58, p.147-159, 2007. http://dx.doi.org/10.1093/jxb/erl165

Ferrari, E.; Paz, A. da; Silva, A. C. da. Déficit hídrico no metabolismo da soja em semeaduras antecipadas no Mato Grosso. Nativa, v.3, p. 67-77, 2015. http://dx.doi.org/10.14583/2318-7670.v03n01a12

Grieu, P.; Maury, P.; Debaeke, P.; Sarrafi, A. Améliorer la tolérance à la sécheresse du tournesol: Apports del'écophysiologie et de la génétique. Revue Innovations Agronomiques, v.2, p.37-51, 2008.

Kron, A. P.; Souza, G. M.; Ribeiro, R. V. Water deficiency at different developmental stages of Glycine max can improve drought tolerance. Bragantia, v.67, p.43-49, 2008. http://dx.doi. org/10.1590/S0006-87052008000100005

Lee, G. A.; Crawford, G. W.; Liu, L.; Sasaki, Y.; Chen, X. Archaeological soybean (Glycine max) in East Asia: Does size matter? Plos one. v.6, p.1-12, 2011. http://dx.doi.org/10.1371/ journal.pone. 0026720
Maehler, A. R.; Pires, J. L. F.; Costa, J. A.; Ferreira, F. G. Potencial de rendimento da soja durante a ontogenia em razão da irrigação e arranjo de plantas. Pesquisa Agropecuária Brasileira, v.38, p.225231, 2003. http://dx.doi.org/10.1590/S0100-204X2003000200009 Morando, R.; Silva, A. O. da; Carvalho L. C.; Pinheiro, M. P. M. A. Déficit hídrico: Efeito sobre a cultura da soja. Journal of Agronomic Sciences, v.3, p.114-129, 2014.

Nelson, K. A.; Motavalli, P. P.; Nathan, M. Response of no-till soybean [Glycine $\max$ (L.) Merr.] to timing of preplant and foliar potassium applications in a claypan soil . Agronomy Journal, v.97, p.832-838, 2004. http://dx.doi.org/10.2134/agronj2004.0241

Shao, H. B.; Chu, L. Y.; Jaleel, C. A.; Zhao, C. X. Water-deficit stressinduced anatomical changes in higher plants. Comptes Rendus Biologies, v.331, p.215-225, 2008. http://dx.doi.org/10.1016/j. crvi.2008.01.002

Taiz, L.; Zeiger, E. Fisiologia vegetal. 4.ed.: Porto Alegre, Artmed, 2009. 819p. 